\title{
WHO's bioethics code likely to stir debate
}

[PARIS] A set of bioethics principles drawn up by the World Health Organization (WHO) are likely to form the basis of the first comprehensive international guidelines on the potential risks of developments in biology and medicine.

The draft guidelines are due to be presented to the general assembly of WHO in May. They are likely to prove controversial. For example, they strongly support the rights of populations that are the subject of genetic research to have an "equitable share in the fruits of research, and a financial stake in any profits on resulting products".

They demand that genetic research on populations should respect "group consent, confidentiality, and the protection of the group's identity, culture, reputation and traditional beliefs". And they call for all research results from human genome projects to be made public and their fruits distributed equally.

Patents should not be granted on genes per se, but only on products developed from them, according to the guidelines, which describe the genome as the "common heritage of humankind". The guidelines also call for a ban on the use of genetic information to refuse employment or insurance.

WHO's decision to draw up the guidelines was prompted by the political controversy following the cloning of Dolly the lamb in 1997. This exposed the agency's relative inactivity on bioethical issues, and led to a call from member states and the general

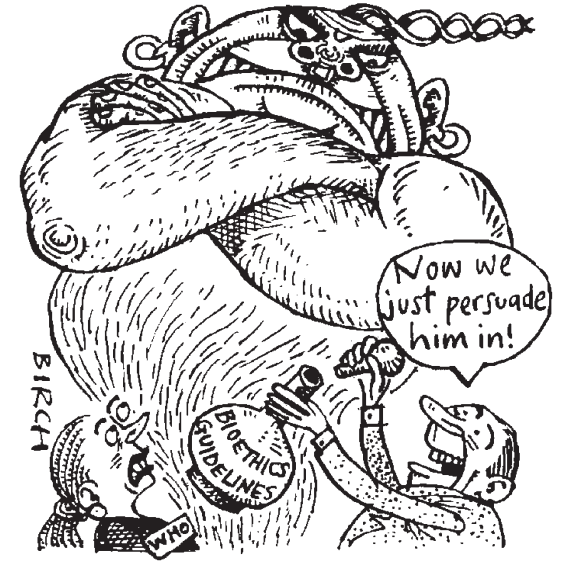

consider to be a consensus on fundamental bioethical principles.

The guidelines will be presented to the general assembly by the current directorgeneral, Gro Harlem Brundtland. Observers say the move is intended to give greater political prominence to the social impact of issues raised by advances in genetics.

"The text is extremely important," says Axel Kahn, a prominent French geneticist and member of the national ethics committee. "It commits not just the countries that have already posed the problem, but all the countries in the world, and requires them to debate these issues."

The United Nations approved a Universal assembly for the organization to take a more active role.

In May 1998, Hiroshi Nakajima, the then director-general of $\mathrm{WHO}$, commissioned recommendations for a strategy on the issue from Abdullah Daar, a transplant researcher and prominent bioethicist from Sultan Qaboos University in Oman, and JeanFrançois Mattei, a physician and member of the French parliament (Démocracie Liberale, Bouches-du-Rhône). The draft guidelines were approved by the WHO executive board in January (full details are published exclusively on http://helix.nature.com/wcs).

The WHO is likely eventually to promulgate the guidelines as an international declaration. Although not legally binding, it would represent a strong political message as to what the organization's member states

\section{India falls into line over patents legislation}

[NEW DELHI] After a delay of more than three years, the Indian parliament finally agreed last week to amend the country's 29-year-old patent law, bringing it in line with other members of the World Trade Organization.

The bill was passed, amid noisy protests and a walk-out by left-wing parties in the Lok Sabha (the lower house), five weeks before the 29 April deadline that had been set by the World Trade Organization's dispute settlement body. The Rajya Sabha (the upper house of parliament) had already approved the bill.

The passage of the Patents (Amendment) Bill 1999 in both houses of parliament means that companies will soon be able to obtain exclusive marketing rights (EMRs) for drugs and agrochemicals and to apply for product patents.

But included in the bill, at the insistence of the opposition Congress party - which voted with the ruling Bharatiya Janata Party in favour of the bill - is a ruling that no EMRs should be given to drugs based on indigenous medicines.
EMRs will be valid for five years, or until the patent application is rejected or granted, whichever comes first. The existing law in India forbids EMRs and provides for patents only on processes, not products.

Under the new law, product patents will be awarded from 1 January 2005 when a 'transition phase' comes to an end and the product patent regime becomes mandatory. "More than 3,000 applications are currently in the 'mailbox' for product patents," says industry minister Sikandar Bakht.

Bakht told parliament that, although companies will benefit from EMRs, the bill contained enough safeguards on pricing, compulsory licensing and powers to revoke EMR licences in the national interest.

Protests against the bill came mainly from communist members of the lower house, who argued that the amendments were "anti-national" and a "sell-out" to multinational companies that want to destroy India's indigenous drugs industry. But, despite the protests, the bill was passed by 231 votes to 55 .

K.S. Jayaraman
Declaration on the Human Genome and Human Rights last year (see Nature 396, 297; 1998). But this is mainly concerned with human rights issues raised by genome research.

The WHO guidelines are more wideranging, says Kahn, and cover "most of the sensitive issues". Kahn applauds in particular the guidelines' affirmation that "hurried and premature legislation in the rapidly-evolving field of genetics can be counterproductive".

Regular review of bioethics legislation to take into account scientific and social change should be the norm, says the text. France, for example, has opted to review its bioethics legislation every five years.

But Kahn is one of several scientists who criticize parts of the text. He points out that a clause stating that germline gene therapy could eventually be acceptable fails to mention that there are few potential therapeutic indications, and fails to outlaw the technique as a means of 'enhancing' the genome.

Another controversial statement is that experiments in developing countries should require the approval of ethical bodies in those countries. Some would prefer it to state bluntly that scientists should not be allowed to carry out experiments in such countries that would not be permitted under the ethical rules they must follow at home.

Daar accepts such criticisms. "These are exactly the sort of comments that we want to take into account before the text goes before the WHO general assembly," he says.

One significant absence from the draft guidelines is any reference to human embryo research. Daar explains that it is impossible to achieve an international consensus on this issue, adding that "if we get a lot of comments saying we must address this issue, we will".

A report accompanying the guidelines that will be submitted by Daar and Mattei to the general assembly calls for WHO to set up a comprehensive unit to "explore the potential impact of new genetic knowledge and technology on health policies". DeclanButler 